\title{
Eeonomies
}

Central European Review of Economics \& Finance

Vol. 28, No. 6 (2018), pp. 77-87

DOI: $10.24136 /$ ceref.2018.033

Received: 15 November 2018. Accepted: 20 December 2018.

Jan L. BEDNARCZYK ${ }^{1}$, Marzena SOBOL ${ }^{2}$

\section{REMARKS ON QE EFFICIENCY IN THE CONTEXT OF NAIRU SHIFTS AND IS-LM APPROACH}

The purpose of the paper is to prove the thesis that the capacities of unconventional monetary policy implemented by the central banks of economically developed countries and aiming at overcoming deflationary and stagnancy processes are becoming exhausted and it will not be in the position to bring about desired effects in the long run in accommodation of economic recovery and, in particular, sustainable improvement in labour market conditions. In consequence, economic authorities of developed countries will be compelled to look for new, more effective methods of supporting recovery.

Keywords: Inflation, unemployment, low inflation trap.

JEL Classification Codes: E12, E58, E62, J64.

\section{Introductory remarks}

One of the most disturbing phenomena which the economies of economically developed countries have had to face for the last dozen years or so, are the deflationarystagnation tendencies which, on the one hand, result in growing unemployment and considerable deterioration of living standards in some countries and, on the other, have a negative effect on the levels of trust in business relationships leading to a limited scope of international cooperation. The first great economy which has been affected by

\footnotetext{
${ }^{1}$ Associate Professor, Ph.D. Habil., Kielce University of Technology, Faculty of Management and Computer Modelling.

${ }^{2}$ Assistent Professor, Ph.D., K. Pulaski University of Technology and Humanities, Faculty of Economic and Legal Sciences.
} 
the contemporary deflationary-stagnation processes ${ }^{3}$ is Japanese economy. It started there more than a quarter of a century ago following a collapse in the real estate market which later developed into a banking crisis and eventually spread across other crucial areas of the financial and production sector. Consequently, in the 1990s and 2000s in Japan the economic growth rate indicated low values, much lower than the average for the OECD countries which resulted, among others, in a lower share of the country in global GDP and the loss of the second, after the USA, place in the rankings of the world's economic superpowers (The Word Bank 2016). The deflationary- stagnation processes in Japan developed despite hard efforts of subsequent governments to reverse them. One of the government's undertakings, already in the 1990s, was, among others, implementing the forward guidance practice and quantitave easing, which later became a "standard” for many major central banks including the Federal Reserve System (FRS) and European Central Bank (ECB).

Although Japan is considered to be a classical example of an economy which cannot cope with stagnant economic growth in the situation of a strong deflationary pressure, yet very similar tendencies are observed also in the eurozone and, to some extent, also in American economy. The ECB's strict observation of its mandate which is maintaining the price growth index close to $2 \%$, actually regardless of the economic situation, caused that the eurozone countries economies are by no means immune to external shocks, which was revealed, among others, by a dramatic worsening of the economic situation in southern Europe following the $2007+$ crisis and the crisis which is sustained there in the debt market. On the other hand, the United States managed to overcome the stagnation process after the financial crisis owing to the use of the so called unconventional methods of monetary policy (quantitative easing and forward guidance) on an unprecedented scale, yet effectiveness of these activities is gradually dying out and their time-deferred effects for economic growth and employment are dificult to estimate. The doubts emerging in connection with the American economy prospects after the positive (transitory) effects of the anti-crisis actions have died out may also question effectiveness (especially in the area of reducing high unemployment) of the unconventional methods implemented by the European Central Bank since 2015.

The purpose of this paper is to prove the thesis that the potential of the policy implemented by central banks of the major economically developed countries which aims at overcoming the deflationary-stagnation processes developing there, is gradually becoming exhausted and in a long-term perspective it will not be able to bring about the desired changes in the economic situation and, in particular, sustainable improvement in the labour market. Consequently, these countries will be compelled to seek new, more effective tools for supporting economic revival.

\footnotetext{
${ }^{3}$ The word "contemporary" is used to differentiate between current deflationary-stagnation tendencies in economies of the developed countries and the tendencies observed there in the inter-war period and earlier
} 


\section{The inflation targeting policy and the nature of price expectations of economic entities}

One of the more important changes which has occurred in the way the economic policy in developed countries has been articulated in the last quarter of the century is ultimate departure from formulating the objectives of the said policy in the policy mix terms, i.e. seeking a compromise between pursuing price stability and ensuring economic growth which would allow keeping unemployment around the "natural" level by means of both monetary and fiscal policy tools. It has been replaced with the policy which treats fighting inflation as a priority, since inflation is regarded as the greatest threat for long-term economic growth and hence employment.

These changes complied with the new consensus logic (Goodfriend, King 1998: 2-3; Woodford 2009: 267-269; Arestis 2009: 2-3), between the Neo-Keynesian and neo-monetarist trends, which gradually developed in the 1980s and 1990s, based, among others on a conviction that in the future the inflationary pressure will remain the main problem of developed market economies and appropriate systemic safeguards (e.g. making central banks independent from the government policy) must be developed to solve this problem effectively. A postulate of non-inflationary growth and superiority of monetary policy as a tool implementing it resulted from the experiences of developed capitalist countries gained in a very specific economic situation of the 1970s when a rapid rise of oil prices in those countries caused a supply shock, which resulted in an unprecedented inflation acceleration. The inflationary impulse was halted only after a radical change in the economic policy where the leading role was assigned to monetary policy based on the money supply control recommended by monetarists. The success of monetary policy in the field of price stabilization was spectacular enough to obscure the fact that the countries which had adopted that policy at the beginning of the 1980s (the United States, Great Britain) in those days faced the strongest economic recession since World War 2 which was also accompanied by a substantial rise in unemployment rate (Bednarczyk 1984: 1314-1320).

In the 1990s in many countries prioritizing inflation was reflected in the implementation of the inflation targeting doctrine together with its specific infrastructure (public announcement of the inflation target and monitoring its progress, publishing reports on inflation, meticulous discussion of the rulings made by the central bank decision-making bodies, etc.). Even in the USA where the central bank is obliged to observe the so called "Dual Mandate" the implicite inflation target was a key measure of the monetary policy character.

Another indicator of this character was the level of the non-accelerating inflation rate of unemployment (NAIRU) estimated for each country. There were many attempts to answer the question at what unemployment rate inflation tends neither to fall nor to rise reflecting ideal equilibrium in the labour market. To this end long-term time sequences 
of demand for labour and labour supply, real wages, productivity, employment structure, the power of trade unions, rates of unemployment benefits etc. were studied. The basis of the NAIRU concept was a view that the labour market is the main source of inflation, hence it is necessary to affect this market in such a way as to prevent it from generating inflationary impulses. The main issue was not to permit a situation when the real unemployment rate would be permanently lower than the NAIRU value estimated for a given country, as otherwise it might threaten with initiating an uncontrolled inflation process.

A particular role in formulating and justifying economic policy based on strict inflation control had the Taylor rule (Taylor 2010). It was used to define a specific level of the basic short-term interest rate of the central bank depending on the divergences of actual inflation from the target inflation and actual GDP from potential GDP. Although compliance of the central bank with the Taylor rule was to ensure long-term stable economic growth, yet in the case of upward divergences of inflation from the inflationary target it implied an increase in interest rates which caused more than a proportional fall of real GDP growth and corresponding to it unemployment rate growth (Taylor 2010: 105-106). Officially no central bank admitted to following the Taylor rule as the basis of its monetary policy; nonetheless it was used by analysts, economic journalists and experts assessing the quality of the said policy. These circles, having a secondary effect (as the so-called market expectations) on the opinions of decision-makers caused that this policy was virtually compliant with the principles of anti-inflationary orthodoxy.

This almost commonly implemented in the developed countries policy of making a fight with inflation a priority resulted in continuous extinguishing of inflationary expectations in these countries in the 1990s and 2000s and consequently real inflation. The important factors which strengthened these tendencies were: the way in which developed countries reacted to global crises of the first decade of the 21 st century (permanent price rise control) and a sustainable entry of Chinese economy into the world economy which, on the one hand, caused a "transfer" of a considerable number of jobs from America and Europe to China (this reduced a pressure on a wage increase in developed countries) and, on the other, a massive inflow of cheap Chinese products to these markets which drove much more expensive American and European products away from the markets, in this way contributing to much lower general price levels.

Treating unemployment as an „output” manifesting itself by a quick and decisive reaction of central banks to even minor divergences of real inflation from the set (usually ambitious) target (the phenomenon of inflationary hysteresis) (Bednarczyk 2013), and lack of appropriate reaction to even a considerable increase in the unemployment rate, including also that assuming a chronic character (vide the eurozone), caused a change in the attitudes of market participants towards the way of considering the price rise in costs calculations, receivables, profits and the scope of their market activities. 


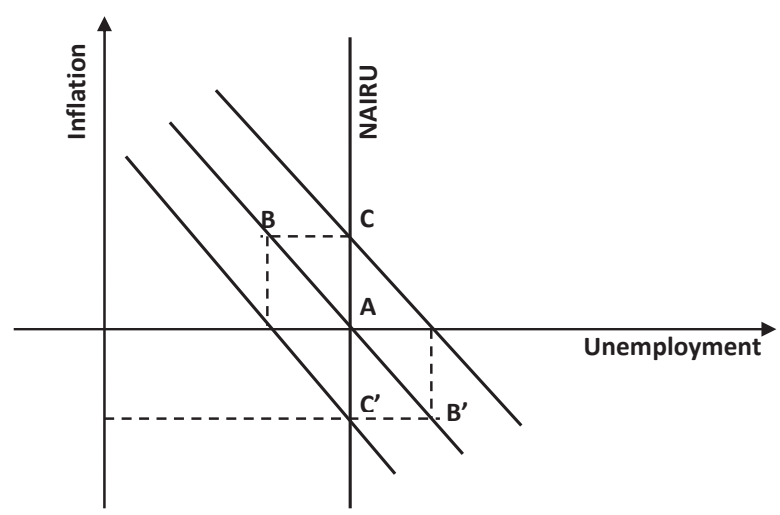

Figure 1. A shift of the short-run Phillips curve in the situation of inflationary and deflationary expectations

Source: (Bednarczyk, 2018).

The nature of changes which occurred in the market in the last twenty-five years can be presented with the use of the expectations-augmented Phillips curve. In Figure 1 points $A, B$ and $C$ represent "classical" changes in the microeconomic equilibrium states in response to a demand impulse caused by expansionary monetary policy (increased money supply). Equilibrium in point $B$ is of temporary character only; the lower than natural unemployment is soon paid for by fuelling inflationary expectations and a shift of the short-run Phillips curve upwards to the right. Each next move of the authorities aiming at lowering the unemployment rate below the natural level will lead to increased instability of inflationary expectations and increasingly higher inflation. Over time the line defining the NAIRU level may lean to the right ${ }^{4}$, which means permanently higher inflation and unemployment.

The example of Japanese economy (but also those of American and European economies) shows that at least since the 2000s, the "classical" mechanism of fuelling inflationary expectations and inflation exclusively by means of a monetary impulse has not worked so effectively and unambiguously as monetarists and their followers used to believe (Friedman 1973; Kydland,Prescott 1977: 473-492). This is proved by the data regarding inflation in the situation of the quantitative easing programmes implemented in economically developed countries. There are strong indications that this mechanism has been replaced with a new way of formulating price expectations by economic entities in the situation when they became aware that the authorities will not allow any price increase. Changes in the states of macroeconomic equilibrium corresponding to a new

\footnotetext{
${ }^{4}$ It is connected with a weaker informative function of prices and deterioration of market mechanism effectiveness
} 
character of expectations are outlined in Figure 1 by a movement from point $A$ to point $B^{\prime}$ and then $C^{\prime}$. Sticking by the authorities to the pursuit of the inflation target may confirm enterprises in a belief that the authorities, while seeking the pro-supply growth factors and aiming at reducing pressure on a wage increase, will tolerate unemployment higher than natural. Their intentions are determined by a hard anti-inflation line expressed by maintaining relatively high real interest rates which effectively block faster increase in nominal income. The effects of a "low inflation trap" (Bednarczyk 2010: 15-26) occur, i.e. an increase in the expected long-term interest rates due to anchoring deflationary expectations. Higher unemployment which is a result of pessimistic expectations as regards economic growth prospects entails a further drop in demand and, at a given supply function - a decrease in price levels (a shift of equilibrium to point $B^{\prime}$ ). This equilibrium (very unfavourable for economy) may not be so permanent because a drop in price levels leads to an increase in the real amount of money which, in turn, alleviates a restrictive impact that the long-term real interest rate mechanism has on economy. Economy may head towards equilibrium in point $C^{\prime}$, to which the unemployment rate at the NAIRU level corresponds, but also a tendency to a drop in price levels. Like in the case of growing inflationary processes, also in the case of deflationary tendencies there is a risk of a difficult to control deflationary-stagnation process development (vide Japan) (Bednarczyk 2015: 89-102), which may result in a permanently decreased economic growth rate and higher unemployment rate. This rate may diverge higher and higher from the rate which so far has been perceived as natural (NAIRU), which causes a decisive limiting of the function of the latter as a benchmark of the monetary policy practised.

The impact of deflationary expectations on changes in long-run macroeconomic equilibrium is presented in Figure 2. Let us assume that the initial state of analysis is point $A$, which corresponds to the positive inflation rate and unemployment rate at the NAIRU level. The authorities decide that the inflation rate so far has been too high and must be reduced and kept at a low level (e.g. $2 \%$ ) irrespective of the conditions in which economy functions (including external shocks). The main tool that the authorities use is increasing interest rates. Initially economic equilibrium shifts to point B (with no effects for economic growth and employment), but, at the same time onto the Phillips curve which is in a lower position and which corresponds to a gradual reduction of inflationary expectations. A fall in inflation means an increase in real interest rates; this leads to limiting the scale of business activities and increased unemployment (equilibrium in point $\mathrm{C}$ ). The authorities do not react to growing unemployment by quantitative easing as they are afraid of fuelling inflationary expectations and exceeding the set inflation target (such behaviour is in compliance with the Taylor rule logic). Improvement in the labour market results mainly from stopping the wage increase (equilibrium in point $D$ ). Point $\mathrm{D}$, however, lies on the lower located Phillips curve (in connection with further reduction of inflationary expectations) and at the same time on the "broken part" of 
NAIRU (which corresponds to a permanent deterioration of the state of equilibrium in the labour market). If the authorities continue the hard line aiming at keeping inflation around the ambitious inflationary target, economic equilibrium may shift to point $E$ and then $\mathrm{F}$, following the track of inflationary expectations reshaping permanently into deflationary expectations.

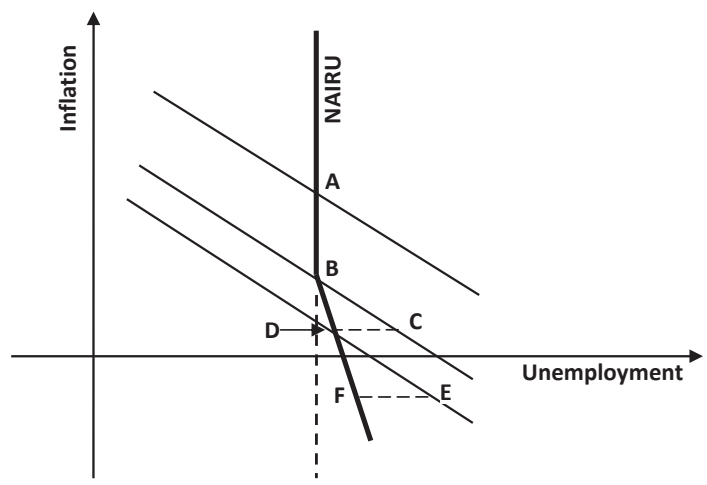

Figure 2. Reaction of the long-run Phillips curve to deflationary expectations Source: (Bednarczyk, 2018).

The presented analysis of macroeconomic equilibrium changes, based on the observations of experiences of the economically developed countries proves that policy of a strict focus on inflation control, in the long run, actually does not allow economy to maintain satisfactory unemployment indicators close to the NAIRU value. A direct effect of implementing the hard anti-inflation line is gradual reduction of price rise expectations and possible occurrence of deflationary expectations which have a negative influence on the economic growth prospects and lead to a permanent deterioration of the situation in the labour market.

\section{Attempts to overcome the deflationary-stagnation processes}

In this situation a question arises: how to overcome the deflation-stagnation processes which develop virtually in all large developed economies as an aftermath of the $2007+$ financial crisis. Implementation of the so-called unconventional tools of monetary policy and, in particular quantitave easing, has become a fairly common practice used by the authorities to stimulate economic recovery. Its effect on the economic situation can be followed with the use of dependencies of the IS-LM model, at the same time taking into account changes in equilibrium in the market of goods (Fig. 3). Let us assume that the initial state of equilibrium is characterized by point $A$ which corresponds to a low inflation rate (1-2 per cent) and weak economic activity. To stimulate recovery 
the authorities decide to significantly increase the money supply. The intention of the authorities is to reach equilibrium in point $B$ (increasing production levels from P1 to P2). However, a considerable part of the increased monetary supply will eventually be spent on the purchase of securities and not goods or services (vide US and Japanese economies), or will "leak out" abroad as a result of a curent account deficit and deficit of portfolio and direct investment. Increased demand for securities will cause the increase in their prices and their lower profitability. At given low inflation this will lead to lower real interest rates. As a result economic equilibrium will be formed in point $C$, which will correspond to only small production growth and the increased inflation index. Despite spectacular actions undertaken by the authorities (because activation of a monetary impulse on a large scale must be regarded as such), economy will remain stuck in stagnation. Continuation of this strategy by the authorities will gradually meet with more and more resistance from the market participants due to its increasingly lower effectiveness and due to difficult to predict effects for economy of the excessive monetary supply growth in the long-run. The latter aspect is relatively important because economic entities, being afraid of the necessity of rapid tightening of monetary policy in the future, may start limiting their production plans now or, for example, transfer their production abroad.

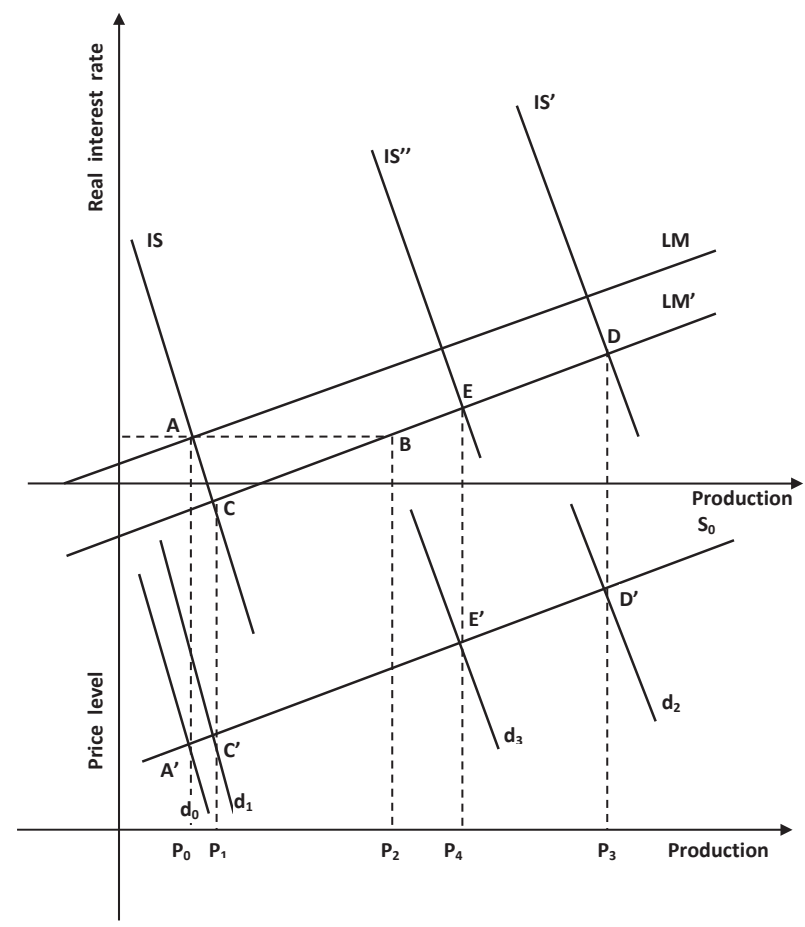

Figure 3. Overcoming the deflationary-stagnation process with the use of the monetary and fiscal policy methods

Source: (Bednarczyk, 2018). 
A way out of the situation when the excess of liquid financial resources in the market, low or even negative long-term interest rates and high unemployment cannot contribute to stimulating economy is an attempt to achieve recovery by the method of shifting the IS curve to the IS' position and economic equilibrium from point $C$ to point $D$. The state can make such an attempt by undertaking, e.g. large-scale infrastructural investment. Such proposals are put forward more and more often in opinions of well-known economists and in economic journalists ${ }^{5}$. Reaching for growth stimulating demand-related factors would probably cause, apart from the growth of the real production volume and employment, a tendency to price rise and, in the long-run, also a tendency to long-term interest rate growth (as a result of increased supply of public securities and a drop in their prices). Economic equilibrium would ultimately be achieved in point $E$, to which a higher than at the initial moment (C) production level (P4), prices and employment would correspond. Long-term unemployment would gradually start to return to the natural state (NAIRU).

While considering the strategy of overcoming the deflationary-stagnation process by stimulation of demand, one should bear in mind the fact that its implementation, e.g. in the EU countries might turn out impossible due to the formal regime of a $3 \%$ ceiling for budget deficit. Paradoxically, implementation of such a strategy would be out of reach for the countries which need it most, where unemployment is at its highest and which experience the greatest economic problems, as they also have the most acute problems with budget deficit. In this situation a dilemma whether to continue pumping "fiat money" into economy in the form of subsequent tranches of quantitative easing which does not bring about expected effects, or to allow a transitional increase in budget deficit which may improve the economic situation and the situation in the labour market, will probably remain unresolved in the European Union.

\section{Conclusions}

Unconventional methods of monetary policy, especially quantitative easing used in economically developed countries are not capable of stimulating economic growth and contributing to the reduction of unemployment. Their potential is so limited that in the United States the option of the so-called secular stagnation is seriously discussed. Such an option could result also in a permanent increase in unemployment rate, which is high anyway, especially in the Eurozone countries which were hit most by the 2007+ crisis. Since in the last twenty-five years monetary policy, a "flagship" tool to form economic

\footnotetext{
${ }^{5}$ An example here is L. Summers from Harvard University, candidate for the Chairman of the Federal Reserve in the 2013 elections, a propagator of the secular stagnation hypothesis who believes that the main problem of the economically developed countries is chronic deficit of demand in the situation of a rising savings rate in aging societies. Cf. P. Coy (2016). Compare also: M. Schuman (2016) and ECB (2016).
} 
equilibrium in developed countries, has lost its ability to revive economy (among others, due to the fact that the nominal interest rates reached the zero lower bound (ZLB)), there is an urgent need to return to the idea of the policy mix, thus taking advantage also of fiscal policy as a tool tantamount to monetary policy in balancing economy. However, a condition to implement the new strategy of supporting economic revival in the European Union is making the budget deficit policy more flexible and adjusting it to new realities, considerably diverging from the reality of the 1980 s when the principles of this policy were formulated.

\section{References}

Arestis P. (2009), New Consensus Macroeconomics: A Critical Appraisal, „The Levy Economics Institute of Bard College", Working Paper No. 564, University of Cambridge, May.

Bednarczyk J.L. (2013), Bank centralny nie stracił wiarygodności, „Rzeczpospolita”, 15.02.2013, ekonomia24.pl. Opinie.

Bednarczyk J. L. (2010), Neutral inflation and the costs of joining and staying in the Eurozone, in: The Mechanism of Functioning of EMU, Euro Zone Enlargement - the New Members' perspective, edited by Bilski Janusz and Feder-Sempach Ewa, „Folia Oeconomica” 239. Acta Universitatis Lodziensis, Łódź.

Bednarczyk J.L.(1984), Pięć lat monetaryzmu w polityce gospodarczej Stanów Zjednoczonych i Wielkiej Brytanii, „Ekonomista” nr 6, s. 1314-1320.

Bednarczyk J.L.(2015), Polityka pieniężna Europejskiego Banku Centralnego a zagrożenie deflacją w Unii Europejskiej, „Kwartalnik Kolegium Ekonomiczno-Społecznego. Studia i Prace”; Oficyna Wydawnicza, Szkoła Główna Handlowa w Warszawie, Narodowy Bank Polski, nr 3, vol. 2 (23), s. 89-102

Bednarczyk J.L.(2018), Polityka stabilizacji cen a przeciwdziałanie recesji. Dylematy współczesnej makroekonomii, PWE, Warszawa.

Coy P. (2016), The Curse of the Big Bad Rut, „Bloomberg Business Week”, May 16-May 22.

ECB. The EBC's fight against low inflation: reasons and consequences. Speech by Peter Praet, Member of the Executive Board of the ECB, at Luiss School of European Political Economy, Rome, 4 April, http://www.ecb.europa.eu (access: 7.05.2016).

Friedman M. (1973), Money. Encyclopaedia Britannica. Macropaedia, vol. 12.

Goodfriend M., R. G. King (1998), The New Neoclassical Synthesis and the Role of Monetary Policy, „The Federal Reserve Bank of Richmond. Working Paper Series”, WP 98-05, Richmond.

Kydland F.E., Prescott E.C. (1977), Rules Rather Then Discretion: The Inconsistency of Optimal Plans, „The Journal of Political Economy”, vol. 85, No. 3, p. 473-492.

Schuman M. (2016), Central Bankers Aren`t Super-Heroes, „Bloomberg Business Week”, April 11-April 24. 
Taylor J.B. (2010), Zrozumieć kryzys finansowy. Przyczyny, skutki, interpretacje, „Wydawnictwo Naukowe PWN", Warszawa.

The World Bank (2016). IBRD-IDA. GDP Ranking 2014. http://data.worldbank.org/data-catalog/ GDP-ranking-table (access: 10.06.2016).

Woodford M. (2009), Convergence in Macroeconomics: Elements of the New Synthesis, „American Economic Journal: Macroeconomics", vol.1, No. 1, p.267-279. 
